(2) Open Access Full Text Article

CASE REPORT

\title{
A case of iridoschisis associated with lens displacement into the vitreous cavity
}

This article was published in the following Dove Press journal:

Clinical Ophthalmology

14 May 2010

Number of times this article has been viewed

\section{Tetsuya Mutoh' \\ Yukihiro Matsumoto' \\ Makoto Chikuda' \\ 'Department of Ophthalmology, Dokkyo Medical University Koshigaya Hospital, Saitama, Japan}

Correspondence:Tetsuya Mutoh Department of Ophthalmology, Dokkyo Medical University Koshigaya Hospital. 2-I-50, Minamikoshigaya, Koshigaya, Saitama, Japan

Tel +8I 48965 I I I I

Fax +8I 48965 ।I27

Email mtetsuya@dokkyomed.ac.jp
Abstract: We report the case of a 67-year-old woman with a lens that was displaced into the vitreous cavity in one eye and ipsilateral iridoschisis. She was free from a history of ocular trauma or of heritable ocular disease. Her best-corrected visual acuity was 1.2 bilaterally and right eye showed signs of iridoschisis. The corneal endothelial cell density decreased to 1,263 cells $/ \mathrm{mm}^{2}$ in the right eye preoperatively. We speculated that iris tissue flowing in the anterior chamber might have intermittently touched the corneal endothelium. 25-gauge pars plana vitrectomy and lens removal were performed immediately. Free-floating iris tissue was cut during surgery with care not to injure the corneal endothelial cells. The postoperative progress was satisfactory and scleral fixation of an intraocular lens is planned. Iridoschisis is an uncommon cause of lens displacement into the vitreous cavity.

Keywords: lens displacement, vitreous cavity, iridoschisis, corneal endothelial cell density, free-floating iris tissue

\section{Introduction}

Iridoschisis is an uncommon condition characterized by separation of the anterior iris stroma from the posterior stroma. ${ }^{1}$ Iridoschisis is a rare disease, of which a only few cases have been reported. ${ }^{2}$ Most patients are aged over 65 years and the condition is usually bilateral, ${ }^{2,3}$ associated with angle-closure glaucoma, ${ }^{3-5}$ trauma, ${ }^{4}$ and syphilitic interstitial keratitis. ${ }^{6}$ Iridoschisis presents with two or more layers of iris tissue that usually is characterized by iris fibers flowing in the anterior chamber. ${ }^{7}$

In 2001, Agrawal et al reported the rare association of unilateral iridoschisis and ipsilateral lens subluxation. ${ }^{5}$ In 2004, Adler et al reported unilateral iridoschisis and bilateral lens subluxation. ${ }^{8}$ To the best of our knowledge, the current report is the first about unilateral iridoschisis and ipsilateral lens displacement into the vitreous cavity.

\section{Case report}

A 67-year-old woman presented with visual loss in the right eye of two months duration. The patient had no history of ocular trauma or other diseases. Her best-corrected visual acuity (VA) was 1.2 bilaterally. Her spherical equivalent refractive error was +11.75 diopters (D) in the right eye and $-0.75 \mathrm{D}$ in the left eye. The intraocular pressure was $15 \mathrm{mmHg}$ in the right eye and $19 \mathrm{mmHg}$ in the left eye. Slit-lamp examination showed 
sectoral schisis of the right iris stroma inferonasally from the 4 to 6 o'clock position (Figure 1). A normal peripheral anterior chamber was seen in the right eye, but no lens was present (Figure 1). The iris, anterior chamber, and lens were normal in the left eye. Postmydriatic examination showed lens displacement into the vitreous cavity in the right eye (Figure 2), and no abnormalities in the left eye. The endothelial cell densities in the center were 1,263 cells $/ \mathrm{mm}^{2}$ in the right eye and 2,849 cells $/ \mathrm{mm}^{2}$ in the left eye (Figure 3A, B). Syphilis serologies were negative.

A 25-gauge pars plana vitrectomy and lens removal were performed immediately in the right eye. Iris tissue flowing into the anterior chamber was cut with a vitreous cutter during surgery. One month postoperatively, the VA was 1.0, and the spherical equivalent refractive error was $+11.25 \mathrm{D}$. The endothelial cell density inferotemporally was 763 cells $/ \mathrm{mm}^{2}$, 2,525 cells $/ \mathrm{mm}^{2}$ superotemporally, and 1,623 cells $/ \mathrm{mm}^{2}$ in the center (Figure $4 \mathrm{~A}-\mathrm{C}$ ). The postoperative progress has been satisfactory and we are planning scleral fixation of an intraocular lens.

\section{Discussion}

We considered that lens subluxation had worsened to lens displacement into the vitreous cavity in this patient. Based on previous reports, it is plausible that iridoschisis is related to lens subluxation or lens displacement into the vitreous cavity. ${ }^{5,8}$ However, Adler et al reported unilateral iridoschisis in the right eye and bilateral lens subluxation; ${ }^{8}$ that the patient presented with lens subluxation without iridoschisis in the left eye and had a longstanding history of periocular eczema. ${ }^{8}$ Our current patient had no such general complications. Future studies will clarify the connection between iridoschisis and lens subluxation or lens displacement into the vitreous cavity.

The corneal endothelial cell density decreased to 1,263 cells $/ \mathrm{mm}^{2}$ preoperatively in our patient. Penetrating keratoplasty was performed in one case ${ }^{8}$ due to localized bullous keratopathy. It is interesting to confirm the presence of iridocorneal contact overlying the area of iridoschisis using ultrasound biomicroscopy. ${ }^{1}$ Although there was no clinical evidence of iridocorneal contact in the current case, we speculated that intermittent iridocorneal touch might

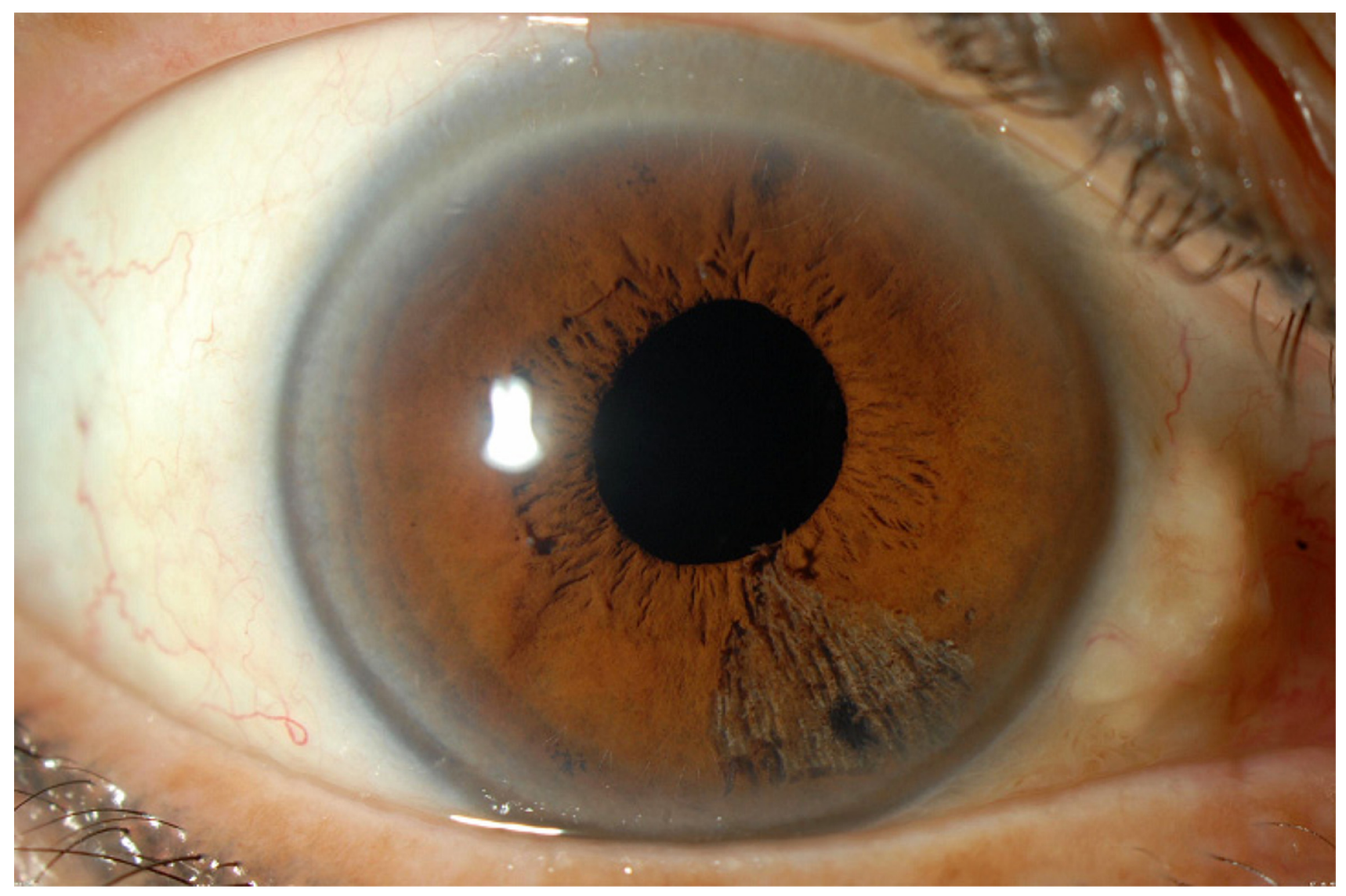

Figure I Preoperative anterior segment of the right eye. Inferonasal iridoschisis is seen and no lens is present. 


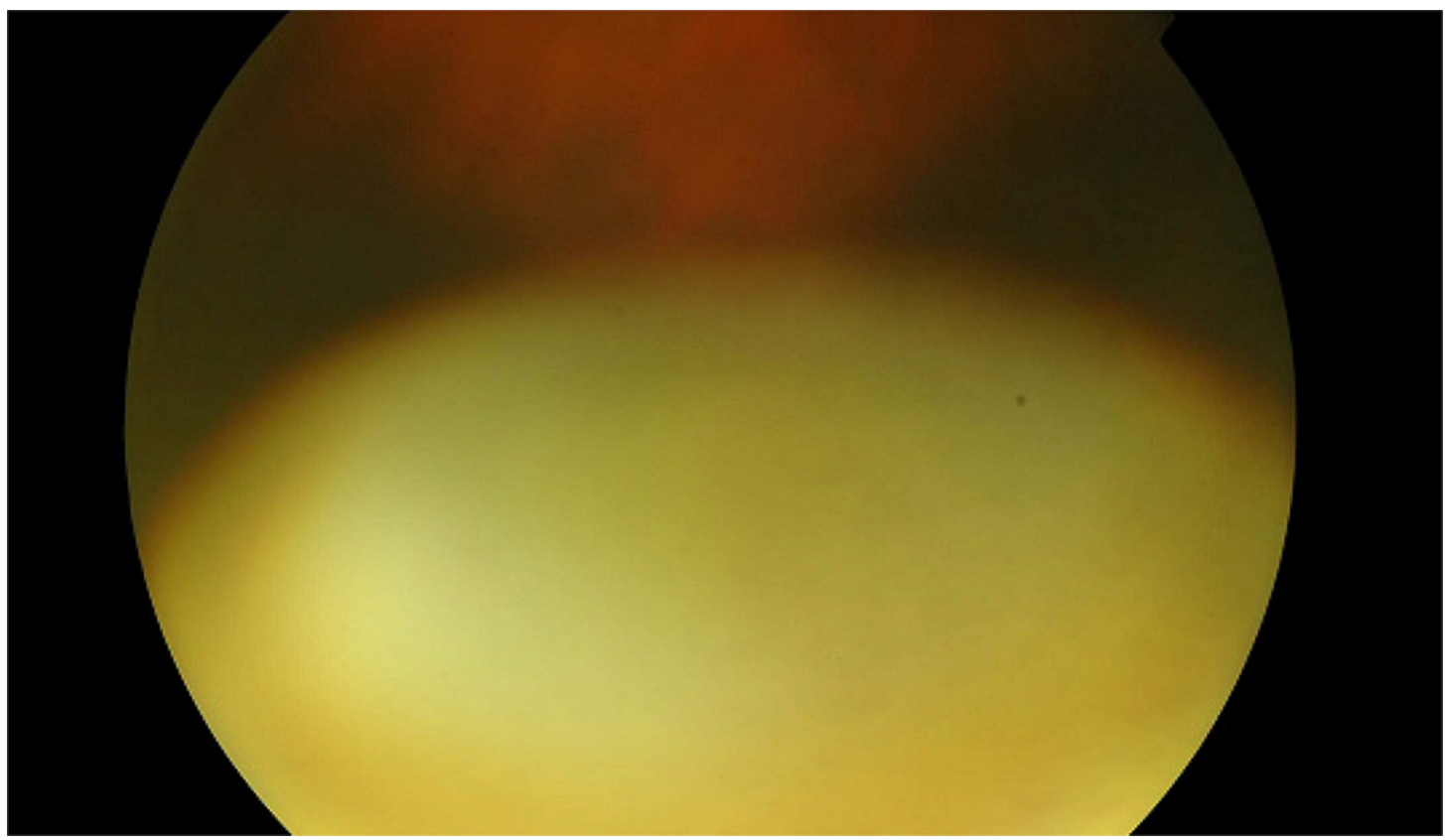

Figure 2 Preoperative ocular fundus examination of the right eye. The lens has been displaced into the vitreous cavity.

have caused this change, as Srinivasan et al reported, ${ }^{1}$ as the free end of the iris fibers sometimes seemed to be in contact with the corneal endothelium before surgery. In addition, there was a report that the iris fibers touched the corneal endothelium, and caused decreasing corneal endothelial cell density. ${ }^{9}$ Finally, the inferonasal endothelial cell density, which corresponds to iridoschisis, decreased extremely after surgery. We cut iris tissue flowing into the anterior chamber during surgery, with care not to injure the corneal endothelial cells. Patients with iridoschisis should undergo specular microscopy to determine the status of the corneal endothelial cells.

We report a case of iridoschisis with lens displacement into the vitreous cavity of the right eye. The postoperative
A

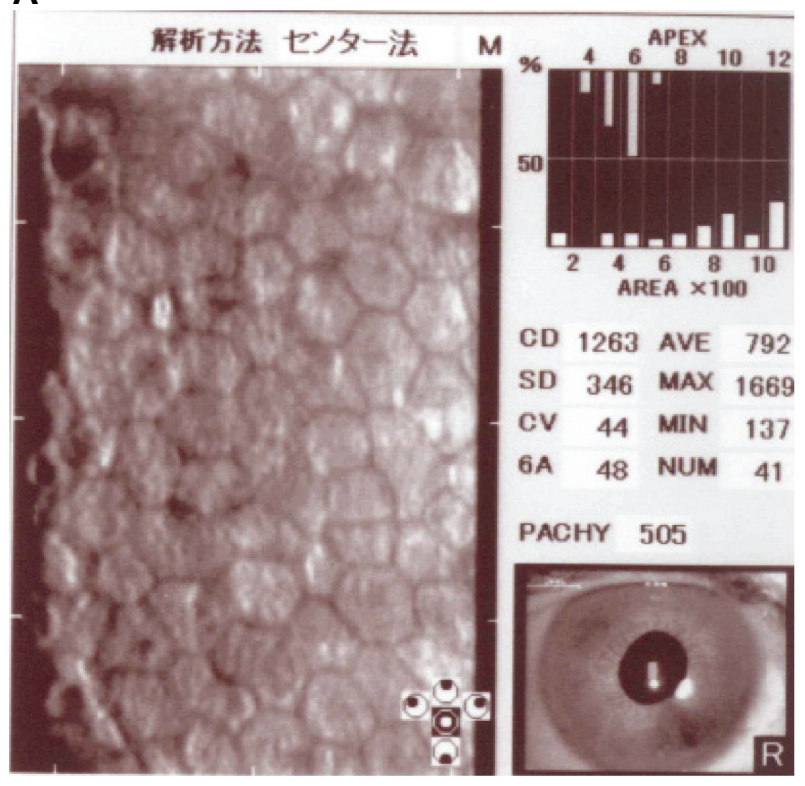

B

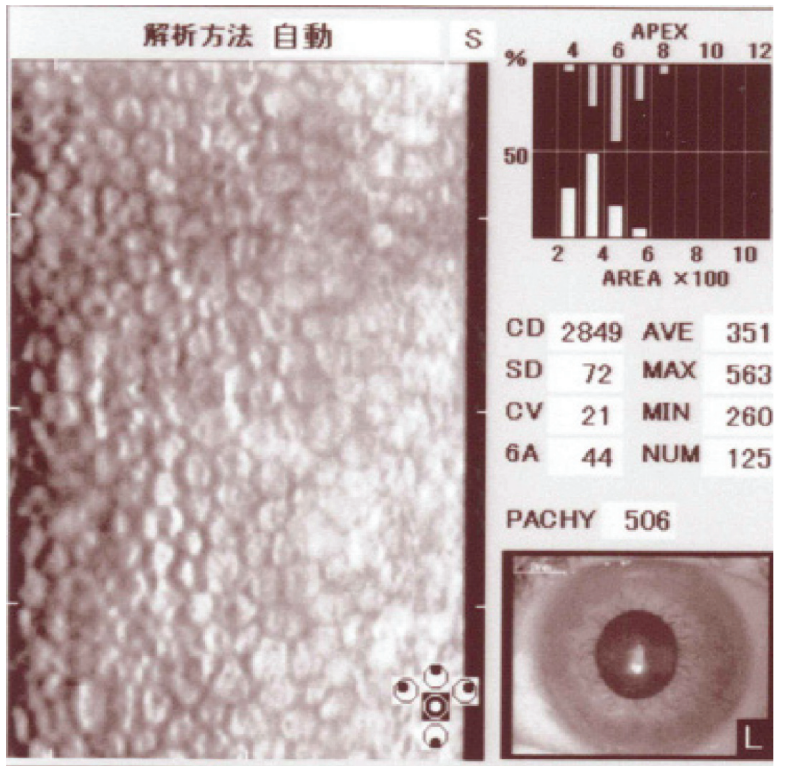

Figure 3 The preoperative endothelial cell density in the center of each eye. A) The endothelial cells are spread out in their area of the right eye. B) The endothelial cells have a normal distribution in the left eye. 
A

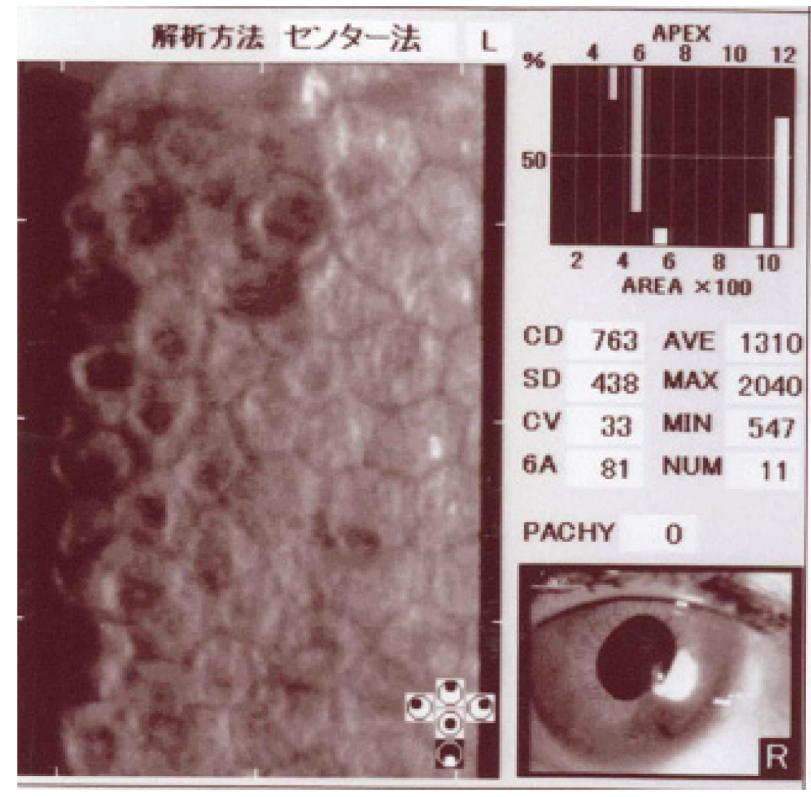

B

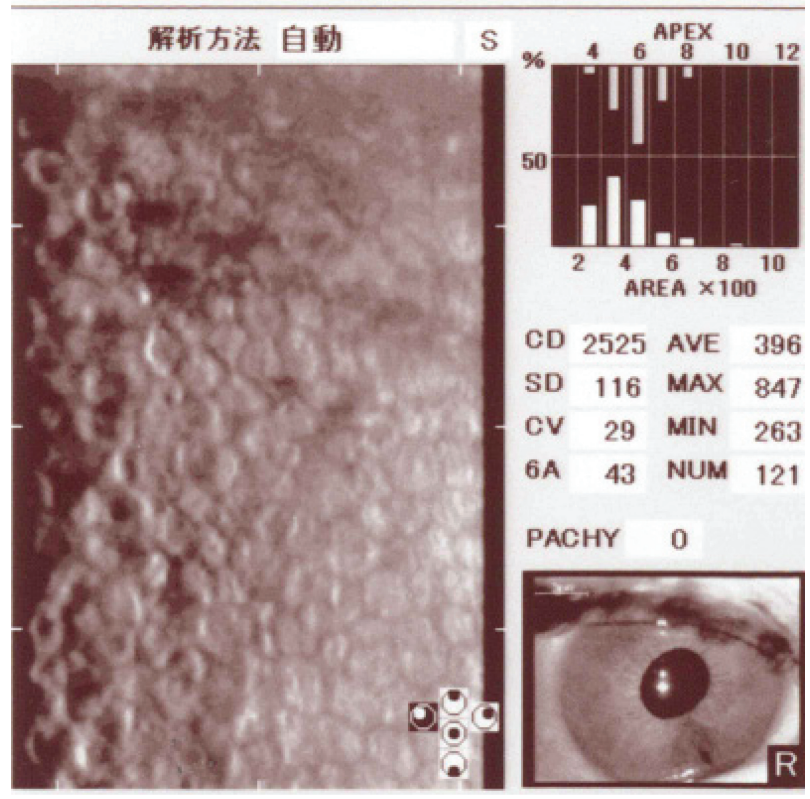

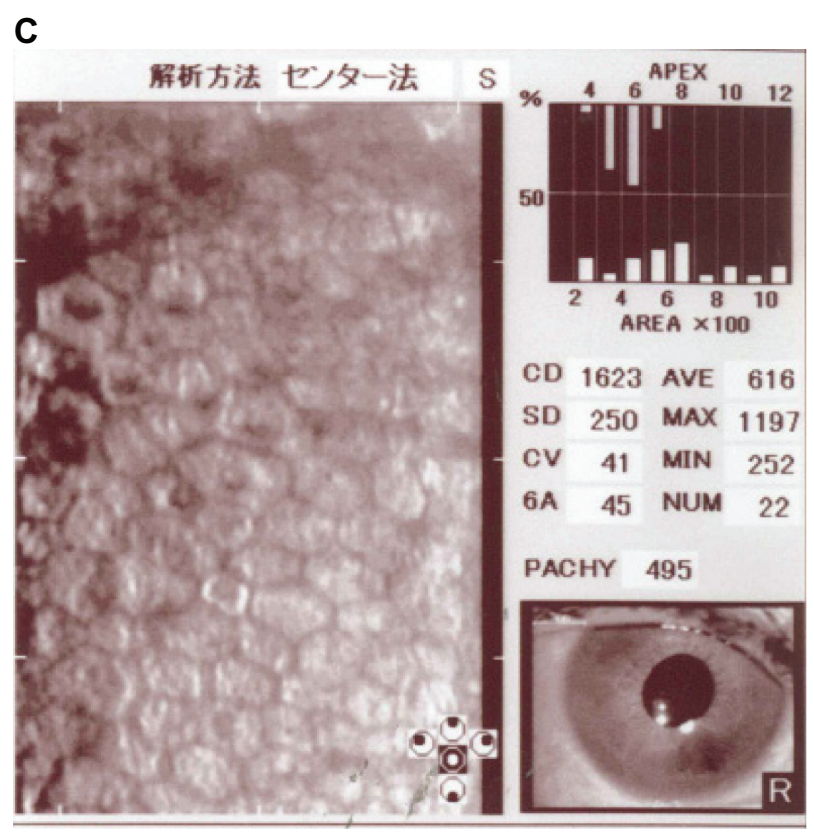

Figure 4 The endothelial cell density in the right eye I month after surgery. There is a marked difference according to each side. A) The inferonasal side. B) The superotemporal side. C) The center.

progress has been good but the corneal endothelial cell density decreased from preoperatively. We will continue to observe the patient. Iridoschisis is an uncommon cause of lens displacement into the vitreous cavity.

\section{Disclosures}

The authors declare no conflicts of interest.

\section{References}

1. Srinivasan S, Batterbury M, Hiscott P. Bullous keratopathy and corneal decompensation secondary to iridoschisis. Cornea. 2005;24:867-869.
2. Lee EJ, Lee JH, Hyon JY, et al. A case of cataract surgery without pupillary device in the eye with iridoschisis. Kor J Ophthalmol. 2008;22:58-62.

3. Kiritoshi A, Ohmi G, Ohji M, et al. Acute glaucomatous attack in a case with iridoschisis. Jpn J Clin Ophthalmol. 1989;43:427-430.

4. Mills PV. Iridoschisis. Br J Ophthalmol. 1967;51:158-164.

5. Agrawal S, Agrawal J, Agrawal TP. Iridoschisis associated with lens subluxation. J Cataract Refract Surg. 2001;27:2044-2046.

6. Salvador F, Linares F, Merita I Amen M. Unilateral iridoschisis associated with syphilitic interstitial keratitis and glaucoma. Ann Ophthalmol. 1993;25:328-329.

7. Auffarth GU, Reuland AJ, Hegar T, et al. Cataract surgery in eyes with iridoschisis using the perfect pupil iris extension system. $J$ Cataract Refract Surg. 2005;31:1877-1880. 
8. Adler RA, Wenberg RS. Iridoschisis and bilateral lens subluxation associated with periocular eczema. J Cataract Refract Surg. 2004;30:234-236
9. Watanabe A, Shikishima K, Noji J, et al. A case of iridoschisis. Jpn J Clin Ophthalmol. 1997;51:593-596.
Clinical Ophthalmology

\section{Publish your work in this journal}

Clinical Ophthalmology is an international, peer-reviewed journal covering all subspecialties within ophthalmology. Key topics include: Optometry; Visual science; Pharmacology and drug therapy in eye diseases; Basic Sciences; Primary and Secondary eye care; Patien Safety and Quality of Care Improvements. This journal is indexed on Submit your manuscript here: http://www.dovepress.com/clinical-ophthalmology-journal

\section{Dovepress}

PubMed Central and CAS, and is the official journal of The Society of Clinical Ophthalmology (SCO). The manuscript management system is completely online and includes a very quick and fair peer-review system, which is all easy to use. Visit http://www.dovepress.com/ testimonials.php to read real quotes from published authors. 